\title{
Hubungan Konsep Diri Dengan Penerimaan Diri Pasien Kanker Payudara
}

\section{Correlation between Self-concept with Self-acceptance in Breast Cancer Patient}

\author{
Ni Made Merlin ${ }^{1}$, Yulianti Toba ${ }^{2}$, Fance Roynaldo Pandie ${ }^{3}$, Antonius Rino Vanchapo ${ }^{4}$ \\ ${ }^{1,3}$ Prodi Profesi Ners, STIKes Maranatha Kupang, Indonesia \\ ${ }^{2,4}$ Prodi Ilmu Keperawatan, STIKes Maranatha Kupang, Indonesia
}

\section{ARTICLE INFO}

\section{Article history}

Received date

10 May 2021

Revised date

16 May 2021

13 Jul 2021

Accepted date

03 Aug 2021

Keywords:

Breast cancer;

Self-acceptance;

Self-concept

\section{Kata kunci:}

Kanker payudara;

Konsep diri;

Penerimaan Diri

\begin{abstract}
ABSTRAK
Breast cancer is one of the most common types of disease in women. The number of breast cancer incidence is always increasing every year. Breast cancer can cause several psychological complaints, one of which is self-acceptance and self-concept. Purpose: the purpose of this study was to see the relationship between self-concept and self-acceptance of breast cancer patients. The study design was cross-sectional with a consecutive sampling technique. This study was conducted in the I inpatient room at the RSUD. Prof. Dr. W.Z. Johannes Kupang. The number of respondents in this study was 50 patients. The statistical test used is chi-square. 25 patients with breast cancer in inpatient room who experienced negative self-concept, most of the breast cancer patients experienced moderate self-acceptance as many as 26 people, statistical test results obtained p-value 0,01 . There is a relationship between self-concept and self-acceptance of breast cancer patients indicated by a $p$-value $<0,05$.
\end{abstract}

Kanker payudara merupakan salah satu jenis penyakit yang paling sering terjadi pada wanita. Jumlah kejadian kanker payudara selalu meningkat setiap tahunnya. Kanker payudara dapat menyebabkan beberapa keluhan psikologis salah satunya penerimaan diri dan juga konsep diri. Tujuan penelitian ini adalah untuk melihat hubungan konsep diri dengan penerimaan diri pasien kanker payudara. Desain penelitian adalah cross-sectional dengan teknik pengambilan sampel consecutive sampling, penelitian ini dilakukan di ruang rawat inap I RSUD. Prof. Dr. W.Z. Johannes Kupang. Jumlah responden dalam penelitian ini adalah 50 pasien. Uji statistik yang digunakan adalah chi-square. Penderita kanker payudara di ruang rawat inap 1 yang mengalami konsep diri negatif sebanyak 25 orang, sebagian besar penderita kanker payudara mengalami penerimaan diri sedang sebanyak 26 orang, hasil uji statistic didapatkan p-value 0,01. Ada hubungan antara konsep diri dengan penerimaan diri pasien kanker payudara ditunjukkan dengan nilai $p$ value $<0,05$.

Corresponding Author:

Ni Made Merlin

Prodi Profesi Ners, STIKes Maranatha Kupang, Indonesia

Email: nimademerlin2@gmail.com

\section{PENDAHULUAN}

Kanker payudara merupakan penyakit akibat dari pertumbuhan sel yang abnormal pada payudara. Kanker payudara merupakan penyakit yang sangat sering dialami oleh wanita. Penyakit ini tidak hanya diderita oleh wanita tetapi ada juga pria yang mengalaminya. Namun, kejadian ini paling sering dialami oleh wanita. Penyakit ini juga menjadi salah satu momok bagi sebagian besar wanita di Indonesia. Jumlah kasus baru penderita kanker payudara selalu meningkat setiap tahunnya (Kementerian Kesehatan, 2016), dan perbandingan kasus baru antara kejadian kanker payudara dengan kanker lainnya adalah sebanyak 25\% (Kementerian Kesehatan, 2017).

Selain itu, kanker payudara juga merupakan jenis kanker yang menyumbangkan 
angka kematian tertinggi dibandingkan dengan beberapa jenis kanker lainnya terutama pada wanita (Kementerian Kesehatan, 2017).

Kanker payudara dapat menyebabkan berbagai masalah ataupun keluhan pada penderitanya. Keluhan-keluhan yang dialami dapat berupa masalah fisik maupun psikologis. Salah satu masalah psikologis diantaranya adalah konsep diri dan juga gangguan penerimaan diri pasien (Chen, S.Q., Liu, J.E., \&Li, 2017; Horgan, Holcombe, \& Salmon, 2011).

Konsep diri merupakan penilaian secara subjektif diri terhadap diri individu tersebut (Drummond, 2013). Konsep diri terdiri dari empat komponen atau sub-variabel yaitu identitas diri, citra tubuh, harga diri dan peran.

Konsep diri dipengaruhi oleh beberapa stresor ataupun perubahan atas empat komponen diatas. Stresor lain yang dapat mempengaruhi konsep diri yaitu penyakit kronis yang dialami (Oeffinger, et al., 2015). Pada pasien kanker payudara yang menjadi stresor adalah beberapa efek samping akibat dari kemoterapi yaitu: kegiatan mutilasi diri atau mastektomi, kehilangan berat badan yang signifikan, alopesia, mual, muntah, stomatitis, fatique atau kelemahan (Kashani, Kashani, Moghimian, \& Shakour, 2015).

Konsep diri diklasifikasikan menjadi dua yaitu konsep diri negatif dan konsep diri positif. Seseorang dengan konsep diri positif cenderung memiliki penilaian yang lebih stabil terkait dirinya sendiri, memiliki motivasi yang tinggi tentang dirinya sendiri (Pratiwi, 2014). Sedangkan konsep diri negatif ditandai dengan ketidakstabilan pandangan diri terhadap dirinya sendiri, tidak memiliki daya juang ataupun motivasi untuk dirinya sendiri.

Konsep diri pasien biasanya berubah-ubah. Tanda atau batasan karakteristik pasien dengan konsep diri yang dapat diperkuat yaitu: menerima keterbatasan yang dialami, menerima kekuatan, tindakan selaras dengan ekspresi verbal, percaya diri dengan kemampuan yang dimiliki, mengekspresikan minat untuk meningkatkan kinerja perannya serta konsep dirinya. Beberapa hal lain juga yaitu: mengekspresikan kepuasan terhadap citra tubuh, identitas pribadi, merasa berharga serta pikiran tentang diri sendiri (NANDA International, 2015).

Selain konsep diri, ada masalah penerimaan diri yang juga sering menjadi masalah psikologis pada pasien kanker payudara. Penerimaan diri merupakan salah satu tahapan dari teori duka cita atau grieving theory milik Kubler-Ross (1969). Salah satu tanda pasien dengan penerimaan diri yang tinggi dapat dilihat dari penilaian yang positif dari penderita tersebut terhadap dirinya sendiri, (Tang, S. T., Chang, W. C., Chen, J. S., Chou, W. C., Hsieh, C. H., \& Chen, 2016) serta memiliki motivasi yang tinggi untuk sembuh (Chen, S.Q., Liu, J.E., \&Li, 2017). Penerimaan diri pada pasien kanker payudara dapat diartikan dengan kemampuan individu atau seseorang dalam bertahan dan nyaman pada situasi atau kondisi penyakit kanker payudara yang sedang dialami (Merlin, N. N., Anggorowati \& Ropyanto, 2019).

Masalah penerimaan diri biasanya dikeluhkan oleh pasien kanker payudara akibat dari ketidaksesuaian antara realita diri dengan harapan utama pasien yang sedang menjalani perawatan. Salah satu penyebab pasien kanker payudara mengalami penerimaan diri rendah yaitu konsep diri pasien yang negatif terhadap dirinya.

Kesejahteraan emosional pasien kanker payudara biasanya dipengaruhi oleh konsep diri akibat dari adanya perubahan citra tubuh, harga diri, kecemasan serta depresi yang dialami (Pintado, 2017). Selain itu, penerimaan diri pada pasien kanker payudara juga dipengaruhi oleh beberapa hal yaitu tingkat pendapatan keluarga atau status ekonomi, tingkat pendidikan, terapi atau tindakan medis yang telah dijalani yaitu kemoterapi maupun mastektomi (Czerw, A., Religioni, U., \& Deptala, 2016).

Penerimaan diri dapat diklasifikasikan menjadi tiga yaitu penerimaan diri rendah, sedang dan tinggi. Ciri-ciri pasien yang memiliki penerimaan diri yang tinggi yaitu: memiliki penilaian positif terhadap penyakit kanker payudara yang dialami dan juga terhadap diri sendiri, memiliki motivasi yang tinggi untuk mengatasi rasa sakit yang dialami, mampu mengontrol gejala, efek samping dari treatment yang sedang dijalani, tidak memiliki ketergantungan fungsional pada orang lain, tidak memiliki perasaan membebani orang lain. Sedangkan, ciri-ciri pasien kanker payudara yang memiliki tingkat penerimaan diri rendah yaitu: pasien cenderung menilai diri secara negatif, kurang memiliki motivasi untuk sembuh dan cenderung bergantung pada orang lain (Czerw, A., Religioni, U., \& Deptala, 2016; Dareng et al., 2015)

Hasil wawancara dari beberapa pasien didapatkan bahwa mereka sering mengeluh tentang kondisi fisik yang sudah tidak seperti wanita normal pada umumnya. Peran sebagai orang tua terutama ibu tidak berjalan sebagaimana mestinya.

Penelitian dari Setiawan, Lestari \& Rachmawati pada tahun 2018 dengan judul "Lama kemoterapi dengan konsep diri pasien kanker payudara yang menjalani kemoterapi di 
RSUD. Ulin Banjarmasin menyatakan bahwa efek samping dari kemoterapi yang menyebabkan terganggunya kondisi fisik serta psikologis terutama konsep diri (Setiawan, Lestari, \& Rachmawati, 2018). Adapun penelitian lain dari Cipora, Konieczny \& Sobieszczanski tahun 2018 dengan judul "Acceptance of illness by women with breast cancer" menyatakan bahwa penerimaan diri pasien kanker payudara juga dapat dipengaruhi dari penurunan harga diri serta gambaran diri seseorang terhadap dirinya (Cipora, E., Konieczny, M., \& Sobieszczanski, 2018).

Keaslian atau keterbaruan dari penelitian ini adalah ada pada alat ukur yang digunakan. Penelitian ini menggunakan alat ukur yang sudah berfokus pada penyakit kanker payudara maupun penyakit kronis. Banyak penelitian tentang konsep diri maupun penerimaan diri tapi alat ukur yang digunakan sebagian besar merupakan alat ukur secara umum tidak berfokus pada penyakit kanker payudara. Selain itu, keaslian penelitian juga ada pada populasi. Penelitian yang sama belum pernah dilakukan pada populasi wanita dengan kanker payudara di Provinsi Nusa Tenggara Timur.

Tujuan penelitian ini adalah untuk melihat hubungan antara konsep diri dengan penerimaan diri pasien kanker payudara yang sedang menjalani perawatan di ruang rawat inap I RSUD. Prof. W.Z. Johannes Kupang.

\section{METODE}

Penelitian ini merupakan jenis penelitian cross-sectional. Teknik pengambilan sampel yang digunakan adalah consecutive sampling. Sampel dalam penelitian ini sebanyak 50 responden. Pengambilan sampel dilakukan dengan menggunakan kriteria yang telah ditentukan oleh peneliti yaitu: kriteria inklusi dan kriteria eksklusi. Kriteria inklusi yang digunakan yaitu: penderita kanker payudara yang sedang menjalani perawatan di rumah sakit, berjenis kelamin perempuan, kesadaran compos mentis, dapat berkomunikasi dengan baik dan tidak memiliki komplikasi penyakit. Kriteria eksklusi yang digunakan, yaitu: pasien tidak dapat berbahasa Indonesia dan pasien mengalami keadaan gawat. Penelitian ini dilaksanakan pada bulan Oktober-Desember 2020.

Pengambilan data dilakukan dengan menggunakan tiga instrumen atau alat ukur yaitu: instrumen pertama untuk data demografi, Acceptance of Illness Scale (AIS) untuk mengukur penerimaan diri dan Merlin Konsep
Diri Kuesioner untuk mengukur konsep diri pasien kanker payudara.

Alat ukur yang digunakan untuk mengukur konsep diri merupakan alat ukur yang telah valid dan reliabel dengan nilai Cronbach alpha 0,909 dan r-tabel 0,50-0,79. Kuesioner ini memiliki 18 pernyataan yang dikembangkan oleh Merlin dan Vanchapo pada tahun 2020 (Merlin \& Vanchapo, 2020). Alat ukur konsep diri terdiri dari empat subvariabel pada komponen yaitu citra tubuh sebanyak lima pernyataan, harga diri sebanyak enam pernyataan, peran sebanyak tiga pernyataan dan identitas sebanyak empat pernyataan. Skoring pengukuran konsep diri dibagi menjadi dua yaitu 0-9 menunjukkan konsep diri negatif dan 10-18 menunjukkan konsep diri positif.

Alat ukur untuk mengukur penerimaan diri menggunakan kuesioner acceptance of illness scale (AIS) yang dikembangkan oleh Felton. Alat ukur ini sudah valid dan reliabel dengan nilai Cronbach Alpha 0.898 serta nilai r-tabel 0.4290.797 (Bien, A., Rzonca, E., Kanczugowska, A., \& Iwanowicz-Palus, 2016; Czerw, A., Religioni, U., \& Deptala, 2016). Kuesioner ini telah disetujui untuk digunakan dan dialih Bahasa ke Bahasa Indonesia. Alat ukur ini terdiri dari delapan pernyataan terkait dengan penerimaan diri seseorang terhadap penyakitnya. Skoring pengukuran penerimaan diri dengan menggunakan skala likert 1 (sangat setuju), 2 (setuju), 3 (tidak tahu), 4 (tidak setuju), 5 (sangat tidak setuju). Total skoring akan dikodingkan menjadi tiga, yaitu: $<20$ penerimaan diri rendah, 20-30 penerimaan diri sedang, $>30$ penerimaan diri tinggi.

Penelitian ini telah lulus uji etik dengan Nomor 98/UN.15.16/KEPK/2020. Nilai etik yang terkandung dalam penelitian ini adalah anonymity/penelitian ini tidak menyebutkan nama pasien dengan jelas namun menggunakan singkatan dan koding, non-maleficience/penelitian ini tidak merugikan pasien, semua informasi disimpan dan tidak disebarluaskan ke publik, dan autonomy/responden diberikan kebebasan untuk mengikuti penelitian secara sukarela dan tanpa paksaan.

\section{HASIL}

Tabel 1. Rerata Usia
\begin{tabular}{cccc} 
Payudara & Penderita & Kanker \\
\cline { 1 - 4 } Variabel & Mean & Min & Max \\
\hline Usia & 46.66 & 23 & 70 \\
\hline
\end{tabular}

Berdasarkan tabel 1 dapat ditunjukan bahwa rata-rata responden berusia 46 tahun 
dengan usia termuda adalah 23 tahun dan tertua berusia 70 tahun.

\begin{tabular}{llrr}
$\begin{array}{l}\text { Tabel 2. } \begin{array}{l}\text { Karakteristik } \\
\text { Payudara }\end{array} \\
\text { Variabel }\end{array}$ & Penderita & \multicolumn{2}{c}{ Kanker } \\
\hline \multirow{2}{*}{$\begin{array}{l}\text { Status } \\
\text { Pernikahan }\end{array}$} & Tidak menikah & 5 & 10 \\
\cline { 2 - 4 } & Janda & 4 & 8 \\
\cline { 2 - 4 } & Menikah & 41 & 82 \\
\hline \multirow{4}{*}{$\begin{array}{l}\text { Status } \\
\text { Pendidikan }\end{array}$} & Tidak sekolah & 1 & 2 \\
\cline { 2 - 4 } & SD & 9 & 18 \\
\cline { 2 - 4 } & SMP & 12 & 24 \\
\cline { 2 - 4 } & SMA & 18 & 36 \\
\cline { 2 - 4 } & Perguruan Tinggi & 10 & 20 \\
\hline \multirow{4}{*}{$\begin{array}{l}\text { Status } \\
\text { Pekerjaan }\end{array}$} & Tidak bekerja & 19 & 38 \\
\cline { 2 - 4 } & Buruh & 4 & 8 \\
\cline { 2 - 4 } & Petani & 8 & 16 \\
\cline { 2 - 4 } & Wiraswasta & 8 & 16 \\
\cline { 2 - 4 } & Pegawai Swasta & 5 & 10 \\
\cline { 2 - 4 } & PNS/TNI/Polri & 4 & 8 \\
\cline { 2 - 4 } & Lain-lain & 2 & 4 \\
\hline \multirow{2}{*}{$\begin{array}{l}\text { Lama } \\
\text { menderita }\end{array}$} & $<1$ Tahun & 15 & 30 \\
\cline { 2 - 4 } & 1-2 Tahun & 16 & 32 \\
\cline { 2 - 4 } & $>2$ tahun & 19 & 38 \\
\hline
\end{tabular}

Berdasarkan dari tabel 2 didapatkan bahwa karakteristik penderita kanker payudara berdasarkan status pernikahan yaitu sebagian besar menikah dengan jumlah 41 responden atau sebesar $82 \%$. Status pendidikan penderita kanker payudara sebagian besar adalah tamatan SMA atau Sekolah Menengah Atas dengan frekuensi 18 atau sebesar $36 \%$. Status pekerjaan sebagian besar tidak bekerja dengan frekuensi 19 atau sebesar 38\%. Dan untuk lama menderita kanker payudara sebagian besar penderita telah mengalami kanker payudara lebih dari 2 tahun dengan jumlah 19 responden atau sebesar $38 \%$.

\section{Tabel 3. Konsep diri dan Penerimaan Diri Penderita Kanker Payudara

\begin{tabular}{llrr}
\hline \multicolumn{2}{c}{ Variabel } & \multicolumn{1}{c}{ n } & $\mathbf{\%}$ \\
\hline \multirow{2}{*}{ Konsep Diri } & Negatif & 25 & 50 \\
\cline { 2 - 4 } & Positif & 25 & 50 \\
\hline \multirow{3}{*}{ Penerimaan Diri } & Rendah & 17 & 34 \\
\cline { 2 - 4 } & Sedang & 26 & 52 \\
\cline { 2 - 4 } & Tinggi & 7 & 14 \\
\hline
\end{tabular}

Berdasarkan tabel 3 didapatkan bahwa konsep diri penderita kanker payudara positif dan negative sama banyak yaitu 25 responden dengan persentase $50 \%$. Penerimaan diri penderita kanker payudara sebagian besar memiliki penerimaan diri sedang sebanyak 26 responden atau dengan persentase $52 \%$.
Tabel 4. Hubungan Konsep Diri dengan Penerimaan Diri Penderita Kanker Payudara

\begin{tabular}{|c|c|c|c|c|}
\hline \multirow[t]{2}{*}{ Variabel } & \multicolumn{3}{|c|}{ Penerimaan diri } & \multirow{2}{*}{$\begin{array}{c}p- \\
\text { value }\end{array}$} \\
\hline & Rendah & Sedang & Tinggi & \\
\hline $\begin{array}{l}\text { Konsep diri } \\
\text { Negatif }\end{array}$ & 13 & 11 & 1 & \\
\hline $\begin{array}{l}\text { Konsep diri } \\
\text { positif }\end{array}$ & 4 & 15 & 6 & 0,01 \\
\hline
\end{tabular}

Berdasarkan tabel 4 didapatkan bahwa sebagian besar penderita yang memiliki konsep diri negatif memiliki penerimaan diri rendah dan sebagian besar penderita yang memiliki konsep diri positif memiliki penerimaan diri sedang. Hasil uji statistic dengan menggunakan uji crosssectional menunjukkan nilai $p$-value 0.01

\section{PEMBAHASAN}

Penderita kanker payudara dapat mengalami gangguan konsep diri negatif maupun positif. Pasien kanker payudara yang memiliki konsep diri negatif biasanya memiliki lebih banyak keluhan dibandingkan dengan pasien yang memiliki konsep diri positif. Sebagian besar keluhan yang dialami terjadi karena adanya kecacatan atau bentuk tubuh yang berubah terutama pada payudara.

Masalah-masalah yang sering dikeluhkan yaitu adanya luka pada payudara yang menyebabkan aroma yang kurang enak, kebotakan akibat dari kemoterapi yang sedang dijalani, mual dan muntah selama bahkan beberapa hari setelah kemoterapi.

Dari hasil wawancara juga didapatkan bahwa pasien mengeluhkan dirinya tidak mampu merawat suami dan anak atau tidak mampu menjalani perannya sebagai istri dan ibu dengan baik. Ketidakseimbangan yang terjadi pada subvariabel konsep diri inilah yang menyebabkan pasien kanker payudara mengalami gangguan konsep diri (Perry \& Potter, 2005).

Hasil penelitian ini sesuai dengan penelitian sebelumnya dari Aguando dengan judul penelitian "Risk factor associated with increased depressive symptoms among Latinas diagnosed with breast cancer within 5 years of survivorship" pada tahun 2013 yang menyatakan bahwa penderita kanker payudara memiliki konsep diri negatif akibat dari penyakit maupun efek samping pengobatan yang dijalani (Aguado Loi, et al., 2013).

Masalah konsep diri selalu dikeluhkan bukan hanya pada beberapa penderita tetapi sebagian besar penderita selalu mengeluh hal 
yang sama (Horgan, et al., 2011). Penderita kanker payudara yang memiliki konsep diri negatif sebagian besar pada pasien kanker payudara yang telah menjalani perawatan lebih dari 2 tahun. Selama dalam perawatan pasien sering mengalami gangguan fisik yang membuat dirinya merasa tidak nyaman hingga ingin menjauh dari lingkungan sosialnya.

Efek samping yang sering dialami oleh pasien sebagian besar membuat mereka merasakan fatique atau kelemahan yang berat sehingga lebih sering pasien bergantung pada keluarga maupun orang lain untuk memenuhi beberapa kebutuhan dasarnya. Dampak dari efek samping tersebut mempengaruhi konsep diri pasien pada subvariabel harga diri.

Berdasarkan hasil penelitian dan juga beberapa penelitian sebelumnya dapat disimpulkan bahwa sebagian besar pasien kanker payudara yang mengalami konsep diri negatif dikarenakan persepsi terhadap diri mereka sendiri. Beberapa dampak yang dialami oleh pasien berdasarkan subvariabel konsep diri yaitu: masalah pembengkakan atau gangguan pada payudara mempengaruhi citra tubuh pasien.

Pasien dengan usia produktif yang memiliki peran sebagai istri dan juga ibu dan tidak dapat memenuhi peran dirinya mengalami gangguan pada subvariabel peran. Pasien yang memiliki ketergantungan pada orang lain dalam memenuhi kebutuhan bahkan merasa menarik diri dari keluarga atau suami mengalami gangguan konsep diri pada sub-variabel harga diri. Pasien yang mengeluh secara variabel tentang penyakitnya akan membuat dirinya menjadi wanita lemah, ditinggalkan suami menjadi janda mengalami gangguan konsep diri pada subvariabel identitas.

Berbagai faktor yang menyebabkan adanya konsepdiri yang negatif yaitu penyakit yang dialami oleh seseorang dan pola pikir terhadap penyakit tersebut, mereka akan mengkonotasikan diri mereka dalam konotasi negatif, menarik diri dan merasa tidak pantas menjadi seorang wanita. Selain itu, konsep diri juga berhubungan dengan masalah psikologis lain yaitu penerimaan diri. Penerimaan diri merupakan salah satu tahap dari teori duka cita milik Kubler-Ross (Paramita, 2011). Penderita kanker payudara sebagian besar memiliki penerimaan diri sedang. Mereka lebih banyak bercerita tentang pengalaman tentang penyakit yang dialami, namun penderita juga menunjukkan ketidaksukaan terkait kondisi penyakit yang dialami saat ini, sebagian besar dari mereka terlihat memiliki dukungan keluarga yang sangat optimal selama dalam proses perawatan maupun kemoterapi. Dapat dilihat dari anggota keluarga yang setia menemani pasien dari awal pemeriksaan bahkan setiap kemoterapi beberapa anggota keluarga setia menemani dari awal perawatan hingga pulang kerumah. Namun, hal ini berbeda dengan pasien dengan penerimaan diri rendah.

Pasien dengan penerimaan diri rendah mereka terlihat lebih banyak murung, tidak memiliki semangat bahkan ada salah satu pasien menyatakan bahwa penyakit yang dialami adalah kutukan atas segala dosa yang telah dilakukan selama ini. Keluarga mengatakan pasien lebih sering menarik diri dari keluarga maupun lingkungan sosialnya.

Penelitian ini sama dengan hasil penelitian sebelumnya oleh Merlin dengan judul "Karakteristik penderita kanker payudara yang mengalami penerimaan diri rendah" tahun 2019 yang menyatakan bahwa penderita kanker payudara sebagian besar mengalami penerimaan diri rendah hingga sedang, penderita biasanya mengeluh tentang kondisi kesehatan bahkan bentuk tubuhnya saat ini (Merlin, N.M \& Vanchapo, 2019).

Penerimaan diri menurut peneliti berdasarkan hasil penelitian saat ini dan penelitian sebelumnya yaitu proses bagaimana penderita kanker payudara dapat menerima atau mengakui bahwa kanker payudara merupakan bagian dari dirinya saat ini.

Penerimaan diri tidak dapat ditentukan terjadi pada pasien dengan fase atau pada kondisi tertentu. Penerimaan diri pada pasien terlihat tidak merata ada yang mengalami penerimaan diri sedang pada wanita usia tiga puluh lima tahun tetapi ada juga yang mengalami penerimaan diri rendah dengan usia yang sama. Hal tersebut juga sama dengan lama penyakit yang telah diderita maupun efek samping yang selama ini telah dialami. Tetapi, pada pasien dengan penerimaan diri rendah rata-rata memiliki banyak keluhan atau ketidaknyamanan dari dirinya sehingga sebagian besar mereka mengalami konsep diri yang negatif.

Konsep diri memiliki hubungan yang erat dengan penerimaan diri. Penderita kanker payudara yang melihat dirinya secara positif dia akan memiliki penerimaan diri yang lebih tinggi terkait diri individu tersebut.

Pasien dengan penerimaan diri sedang sebagian besar mengalami konsep diri yang positif. Dapat dilihat dari beberapa pasien yang mengatakan bahwa walaupun dirinya menderita kanker payudara dan membutuhkan keluarga untuk memenuhi kebutuhannya. Namun, keluarga tidak pernah mengekspresikan keluhan ataupun merasa terbebani karena mengurus keluarga yang 
sakit kanker payudara. Bahkan ada anggota keluarga yang selalu mendukung untuk dapat melakukan hobi ataupun aktivitas yang disukai.

Hasil penelitian ini sejalan dengan penelitian sebelumnya dari Kahe dengan judul "The relationship between self-concept and selfefficacy with self-management among elderly of sanatorium in Tehran" tahun 2018 yang menyatakan bahwa konsep diri positif akan menumbuhkan kepercayaan diri terhadap sesuatu (Kahe, Vameghi, Foroughan, Bakhshi, \& Bakhtyari, 2018). Selain itu, penderita kanker payudara yang memiliki penerimaan diri rendah selalu memiliki persepsi yang negatif tentang dirinya (Merlin, N. N., Anggorowati \& Ropyanto, 2019).

Hubungan antara konsep diri dan juga penerimaan diri yaitu sebagian besar responden mengatakan bahwa mereka tidak mampu menyesuaikan diri dengan keterbatasan yang diakibatkan oleh penyakit ini. Keterbatasan yang dialami juga membuat mereka rata-rata kehilangan kemampuan diri untuk melaksanakan peran mereka. Sebagian besar bahkan sangat bergantung pada orang lain untuk memenuhi kebutuhan dasar mereka. Bahkan peran mereka sebagai seorang ibu atau istri juga tidak dapat berjalan sebagaimana mestinya. Selain itu dari hasil uji statistik yang didapatkan juga menjelaskan bahwa ada hubungan yang signifikan antara konsep diri dengan penerimaan diri pada pasien kanker payudara.

Berdasarkan hasil temuan pada penelitian ini sebagian besar penderita kanker payudara mengalami kelemahan yang berat sehingga mereka enggan untuk beraktifitas ataupun memenuhi kebutuhan dirinya. Peneliti akhirnya menyarankan untuk peneliti selanjutnya dapat meneliti tentang hubungan antara fatique dengan konsep diri pada pasien kanker payudara maupung hubungan antara fatique dengan penerimaan diri pada pasien kanker payudara.

\section{DAFTAR PUSTAKA}

Aguado Loi, C. X., Baldwin, J. A., McDermott, R. J., McMillan, S., Martinez Tyson, D., Yampolskaya, S., \& VandeWeerd, C. (2013). Risk factors associated with increased depressive symptoms among Latinas diagnosed with breast cancer within 5 years of survivorship. Psycho-Oncology, 22(12), 2779-2788. https://doi.org/10.1002/pon.3357.

Bien, A., Rzonca, E., Kanczugowska, A., \& Iwanowicz-Palus, G. (2016). Factors affecting the quality of life and the illness

\section{SIMPULAN}

Konsep diri pasien kanker payudara terdiri dari dua yaitu konsep diri negatif dan positif. Sebanyak dua puluh lima responden mengalami konsep diri positif dan sebanyak dua puluh lima responden mengalami konsep diri negatif. Penderita kanker payudara yang memiliki konsep diri negatif sering mengeluhkan dirinya tidak menyukai bentuk tubuhnya terutama pada area payudara, bentuk payudaranya maupun masalah yang terjadi pada payudaranya, penderita kanker payudara tidak dapat melaksanakan perannya sebagai wanita, istri maupun ibu dengan baik.

Sebanyak dua puluh enam responden mengalami penerimaan diri sedang. Penderita kanker payudara yang memiliki penerimaan diri sedang biasanya mengeluh terkait kondisi penyakit dan terkadang kooperatif dalam perawatan. Penderita dengan penerimaan diri sedang juga dapat dilihat dari mereka senang dan lebih banyak bercerita pengalaman tentang penyakit yang dialami, namun penderita juga menunjukkan ketidaksukaan terkait kondisi penyakit yang dialami saat ini, sebagian besar dari mereka terlihat memiliki dukungan keluarga yang sangat optimal selama dalam proses perawatan maupun selama menjalani kemoterapi.

Hubungan antara konsep diri dan penerimaan diri dapat dilihat dari hasil uji statistik yang menunjukkan hasil $p$-value $<0,05$. Hasil ini menunjukkan hasil yang signifikan yang dapat diartikan bahwa ada hubungan yang signifikan antara konsep diri dengan penerimaan diri pasien kanker payudara, Pasien dengan konsep diri negatif memiliki persepsi diri yang negatif terkait dirinya sendiri sehingga tidak mampu menerima penyakitnya sebagai bagian dari dirinya.

acceptance of pregnant women with diabetes. International Journal of Environmental Research and Public Health, 13(68), 1-13. https://doi.org/10.3390/ijerph13010068.

Chen, S.Q., Liu, J.E., \&Li, Z. (2017). Selfacceptance and Associated Factors. Journal of Clinical Nursing, 11(12), 15161523. https://doi.org/10.1111/jocn.13437

Cipora, E., Konieczny, M., \& Sobieszczanski, J. (2018). Acceptance of illness by women 
with breast cancer. Annals of Agricultural and Environmental Medicine, 25(1), 167171. https://doi.org/10.26444/aaem/75876

Czerw, A., Religioni, U., \& Deptala, A. (2016). Assessment of Pain, Acceptance of Illness , Adjustment to Life With Cancer and Coping Strategies in Breast Cancer Patients. Breast Cancer, 23(4), 654-661. https://doi.org/10.1007/s12282-015-0620-0

Dareng, E. O., Jedy-Agba, E., Bamisaye, P., Isa Modibbo, F., Oyeneyin, L. O., Adewole, A. S., ... Adebamowo, C. A. (2015). Influence of spirituality and modesty on acceptance of self-sampling for cervical cancer screening. PLoS ONE, 10(11), 1-12. https://doi.org/10.1371/journal.pone.0141679.

Drummond, K. D. (2013). Self-concept, behavioural attributions and selfawareness in adolescents with Autism Spectrum Disorder: A mixed-methods approach. University of Toronto.

Horgan, O., Holcombe, C., \& Salmon, P. (2011). Experiencing positive change after a diagnosis of breast cancer: a grounded theory analysis. Psychooncology, 20(10), 11161125. https://doi.org/10.1002/pon.1825

Kahe, M., Vameghi, R., Foroughan, M., Bakhshi, E., \& Bakhtyari, V. (2018). The relationships between self-concept and self-efficacy with self-management among elderly of sanatoriums in Tehran. Iranian Journal of Ageing, 13(1), 28-37. https://doi.org/10.21859/sija.13.1.28

Kashani, F., Kashani, P., Moghimian, M., \& Shakour, M. (2015). Effect of stress inoculation training on the levels of stress, anxiety, and depression in cancer patients. Iranian Journal of Nursing MMidwifery Research, 20(3), 359-364.

Kementerian Kesehatan. (2016). Info Datin Bulan Peduli Kanker Payudara 2016. Jakarta: Kementrian Kesehatan RI.

Kementerian Kesehatan. (2017). Info DATIN Pusat Data dan Informasi Kementerian Kesehatan RI: Situasi Penyakit Ginjal Kronis. Jakarta: Kementrian Kesehatan RI. www.depkes.go.id/resources/download/pus datin/infodatin.

Kubler-Ross, E. (1969). The Five Stages of Greif. On Death Dying, 627.

Merlin, N. N., Anggorowati \& Ropyanto, C. B. (2019). The effects of quantum psychological relaxation technique on self-acceptance in patients with breast cancer. Canadian Oncology Nursing Journal=Revue Canadienne De Nursing Oncologique, 29(4),
232-236.

https://doi.org/10.5737/23688076294232236

Merlin, N.M \& Vanchapo, A.. (2019). Karakteristik responden Kanker Payudara yang Memiliki Penerimaan Diri Rendah. Jurnal Penelitian Kesehatan Suara Forikes, 10(4), 320-323.

https://doi.org/http://dx.doi.org/10.33846/s f10415.

Merlin, N. M., \& Vanchapo, A. R. (2020). Breast Cancer Self-concept at Prof. Dr. W. Z. Johannes Hospital Kupang. Indonesian Journal of Nursing and Midwifery, 8(2), 95-99. http://dx.doi.org/10.21927/jnki.2020.8(2).9 5-99.

NANDA International. (2015). Diagnosis Keperawatan Defenisi dan Klasifikasi (10th ed.). Jakarta: EGC.

Oeffinger, K. C., Fontham, E. T. H., Etzioni, R., Herzig, A., Michaelson, J. S., Shih, Y.-C. T., ... Wender, R. (2015). Breast Cancer Screening for Women at Average Risk. Jama, 314(15), 1599. https://doi.org/10.1001/jama.2015.12783

Paramita, R. (2011). Pengaruh Penerimaan Diri Terhadap Penyesuaian Diri Penderita Lupus. Jurnal Psikologi Undip, 12(1).

Perry \& Potter. (2005). Buku Ajar Fundamental Keperawatan: Konsep, Proses dan Praktik (4th ed.). Jakarta: EGC.

Pintado, S. (2017). Self-concept and emotional well-being in patients with breast cancer. Revista Iberoamericana de Psicologia $y$ Salud, 8(2), 76-84. https://doi.org/10.23923/j.rips.2017.08.007

Pratiwi, Y. (2014). Gambaran konsep diri pada klien dewasa muda dengan kolostomi permanen di Yayasan Kanker Indonesia Jakarta Pusat. [Skripsi]. Jakarta: Universitas Islam Negeri Syarif Hidayatullah Jakarta. http://repository.uinjkt.ac.id/dspace/bitstream/ 123456789/24184/1/Yuniska Pratiwi-fkik.pdf

Setiawan, M., Lestari, D. R., \& Rachmawati, K. (2018). Hubungan Lama Kemoterapi Dengan Konsep Diri Pasien Kanker Payudara. Dinamika Kesehatan, 9(2), 429-443.

Tang, S. T., Chang, W. C., Chen, J. S., Chou, W. C., Hsieh, C. H., \& Chen, C. H. (2016). Associations of Prognostic Awareness/acceptance with Psychological Distress, Existential Suffering, and Quality of Life in Terminally Ill Cancer Patients' Last Year of Life. Psycho-Oncology, 462(25), 455462. https://doi.org/10.1002/pon.3943. 